\title{
Dinamika Kelompok Perkumpulan Petani Pemakai Air (P3A) Sumber Mulyo dalam Kegiatan Pengelolaan Jaringan Irigasi di Desa Pereng Kecamatan Mojogedang Kabupaten Karanganyar

\author{
(Dynamics of Sumber Mulyo Water User Farmer Farmers' Group in the Activities of Irrigation
} Network Management in Pereng Village Mojogedang District Karanganyar Regency)
}

\author{
Azmul Fauzi*, Joko Winarno, Sapja Anantanyu \\ Program Studi Penyuluhan dan Komunikasi Pertanian, Fakultas Pertanian, \\ Universitas Sebelas Maret, Surakarta, Indonesia \\ Email: wismagedhe@gmail.com
}

\begin{abstract}
The purpose of this research are to know the factors of that affect group dynamic, the result of activities, and the best strategy in development object of this research. This research use indept revew, observation, and document analyst to collecting the datas. And then, the datas will be thought in input stage until the researcher fing the strengths and the weakness of the object. The researcher can find the opportunities and the treats of thi object by using IFE (Internal Factor Evaluation) matrix and EFE (External Factor Evaluation) matrix. The researcher use SWOT (Strengths, Weaknesses, Opportunities, and Threats) matrix to determine the strategies that will be use in the next stage. The result of the research is the most important strength factors are high farmer participation and participatory of the leadership $(0,727)$. While, the weaknesses are low farmer education and the existence of multiple positions in management $(0,409)$. The highest opportunity is attention from the government at the beginning of $P 3 A$ activities (1,333). While the threat factor is the lack of government attention to the current P3A activities (1,000). The result of this research is the strategies can be used for P3A Sumber Mulyo's activities are optimizing P3A Sumber Mulyo activities to faced the problem. The researcher hope to P3A Sumber Mulyo can solve the problem about primary, secondary, and tertiary waterways management and manufacturing and processing of organic fertilizer.
\end{abstract}

Keywords: Group dynamics, P3A, SWOT analysis

\begin{abstract}
Abstrak
Penelitian ini bertujuan untuk mengetahui faktor-faktor yang mempengaruhi dinamika kelompok, hasil kegiatan, dan strategi terbaik dalam pengembangan obyek penelitian. Teknik pengumpulan data yang digunakan adalah wawancara mendalam (in-depth interview), observasi dan analisis dokumentasi. Data yang diperoleh tersebut akan melalui tahap input stage sehingga peniliti mendapatkan kekuatan dan kelemahan penelitian ini. Penentuan peluang dan ancaman dapat diperoleh melalui IFE (Internal Factor Evaluation) dan EFE (External Factor Evaluation). Peneliti menggunakan matrik SWOT (Strengths- Weaknesses- Opportunities- Threats) untuk menentukan strategi yang akan digunakan dalam tahap selanjutmya. Hasil penelitian ini menunjukkan bahwa faktor kekuatan yang paling penting adalah partisipasi petani yang tinggi dan kepemimpinan yang partisipatif $(0,727)$. Sedangkan, aspek kelemahan yang memicu adalah pendidikan petani yang rendah dan adanya rangkap jabatan dalam kepengurusan $(0,409)$. Peluang yang muncul yaitu adanya bantuan alat dari pemerintah pada awal kegiatan P3A(1,333). Sedangkan faktor ancamannya yaitu kurangnya perhatian pemerintah terhadap kegiatan P3A. Hasil dari penelitian ini adalah strategi yang dapat digunakan untuk mengoptimalkan kegiatan P3A Sumber Mulyo dalam memecahkan masalah yang dihadapi. Peneliti berharap agar P3A Sumber Mulyo dapat menghadapi masalah pengelolaan saluran air primer, sekunder dan tersier serta pembuatan dan pengolahan pupuk organic dengan strategi yang telah peneliti susun.waz
\end{abstract}

Kata Kunci: Analisis SWOT, Dinamika kelompok, P3A

Cite this as: Fauzi, A., Winarno, J., \& Anantanyu, S. (2021). Dinamika Kelompok Perkumpulan Petani Pemakai Air (P3A) Sumber Mulyo dalam Kegiatan Pengelolaan Jaringan Irigasi di Desa Pereng Kecamatan Mojogedang Kabupaten Karanganyar. AGRITEXTS: Journal of Agricultural Extension, 45(1), 26-34. doi: http://dx.doi. org/10.20961/agritexts.v45i1.51537 


\section{PENDAHULUAN}

Pertanian adalah salah satu aspek penting dalam kehidupan masyarakat di Indonesia. Salah satu upaya untuk meningkatakan produksi pertanian dengan sapta usaha tani. Salah satu langkah dari sapta usaha tani dengan mengatur irigasi. Hal ini dilakukan karena air memiliki peranan yang sangat penting bagi lingkup pertanian. Selain itu, air juga memiliki pengaruh secara general. Air mutlak diperlukan bagi makhluk hidup untuk tumbuh dan berkembang. Namun, air yang tersedia bagi kebutuhan tanaman tidak dapat selamannya mencukupi kebutuhan pertumbuhan tanaman. Air sepantasnya harus dijaga dan dikelola dengan baik (Novrida, 2008). Dari pernyataan tersebut, petani sebagai pihak yang membutuhkan air perlu langkah bijak untuk mengelola air. Oleh karena itu, petani membentuk suatu kelompok yang disebut dengan P3A (Perkumpulan Petani Pemakai Air).

Menurut Harsoyo dan Suhadi (1982), kelompok tani merupakan wadah berhimpun petani yang terikat atas dasar kesamaan aspirasi, kebutuhan dan tujuan yang sama sehingga menjadi kelompok tani yang berhasil. Begitu pula dengan P3A. Di lain sisi, anggota dalam P3A juga memiliki dinamika di dalamnya. Menurut Deptan (2008), Perkumpulan Petani Pemakai Air (P3A) yaitu sebuah organisasi atau kelembangaan pengelolaan irigasi yang menjadi wadah petani pemakai air dalam suatu daerah pelayanan irigasi yang dibentuk oleh petani pemakai air sendiri secara demokratis, termasuk kelembagaan lokal pengelola air irigasi, dengan kata lain P3A bertujuan untuk memberikan suatu wadah bagi para petani yang memakai air dalam bertani agar lebih produktif. Istiyati (2010), juga mengungkapkan bahwa anggota P3A dapat menikmati manfaat langsung maupun tak langsung dari pengelolaan irigasi untuk menggarap sawah serta memikul tanggung jawab dalam pelaksanaan tugas-tugas irigasi. Terkait dengan hal tersebut, Ini didukung dengan pernyataan bahwa suatu kelompok akan produktif bila anggotannya memiliki keterampilan yang disyaratkan dan karakteristik, pribadi yang baik serta mendapat dukungan dari manajemen ditambah dengan tersediannya sumber daya yang melimpah (Rivai, 2003).

P3A Sumber Mulyo Desa Pereng, Kecamatan Mojogedang, Kabupaten Karanganyar, Jawa Tengah. P3A ini pernah menjadi juara 2 tingkat nasional dan memiliki SK Bupati. P3A Sumber Mulyo berada di bawah naungan organisasi kelompok tani Rukun Makaryo selalu menekankan perlindungan dan konservasi alam untuk melindungi sumber mata air. Mereka sadar bahwa adanya perubahan iklim yang tidak menentu serta kerusakan lingkungan akibat dari penggunaan pestisida yang berlebihan. P3A Sumber Mulyo memberikan inisiatif dan memotivasi petani untuk memanfaatkan bahan dari lingkungan sekitar seperti menggunakan pestisida nabati maupun pupuk organik.

Menurut Santosa (2009), dinamika kelompok tani adalah hubungan interaksi dan interdependensi antaranggota pembentuk kelompok tani. Hal ini juga dapat diartikan sebagai suatu kekuatan yang terdapat dalam suatu kelompok. Hal ini juga yang menentukan serta berpengaruh terhadap perikalu anggota kelompok dalam mencapai tujuan bersama. Mardikanto (1993) mengemukakan bahwa dinamika kelompok adalah bidang kajian yang cenderung diarahkan terhadap kekuatankekuatan dalam suatu kelompok maupun lingkungan sekitar kelom[ok. Lingungan tersebut mampu menentukan perilaku anggota kelompok yang bersangkutan untuk bertindak demi mencapai tujuan bersama.

Daripenjabarantersebut, penelitian inibertujuan untuk mengetahui dinamika yang timbul dalam P3A Sumber Mulyo. Peneliti mengidentifikasi faktor-faktor dapat mempengaruhi timbulnya dinamika dalan kelompok tani tersebut. Peneliti jiga berupaya mengidentifikasi hasil kegiatan yang telah dilakukan kelompok tani tersebut. Serta, peneliti merumuskan upaya, strategi atau langkah terbaik yang dapat dijalankan kelompok tani agar dapat berkembang dalam mengelola irigasi. Hal ini juga turut serta dapat menyejahterakan petani dan berkontribusi pada peningkatan pendapatan bruto pemerintah di bidang pertanian.

\section{METODE PENELITIAN}

Penelitian ini menggunakan pendekatan kualitatif yang memuat penjelasan tentang prosesproses yang terjadi dalam lingkup setempat. Peneliti menentukan informan dengan metode purposive berdasarkan kriteria dengan suatu pertimbangan tertentu. Peneliti menggunakan teknik wawancara mendalam dan menggunakan teknik observasi berperan pasif. Informan yang 
dipilih yaitu penyuluh pertanian, kepala kelurahan, staf kelurahan, pembina atau badan pengawas P3A, pengurus dan anggota P3A. Peneliti juga memperoleh data dari sumber sekunder (sumber tambahan) sebagai pelengkap informasi-informasi yang sudah didapatkan. Peneliti menganalisis data dengan menggunakan 3 tahap yaitu tahap input stage untuk mendapatkan kekuatan dan kelemahan, peluang, dan ancaman melalui IFE dan EFE, kemudian masuk ke tahap SWOT (StrengthsWeaknesses- Opportunities- Threats). Peneliti menggunakan kuisoner, observasi, wawancara mendalam dan dokumentasi untuk sumber data yang sama secara serempak untuk menunjukkan keabsahan data yang diperoleh.

\section{HASIL DAN PEMBAHASAN}

P3A Sumber Mulyo adalah kelompok tani mengatur pembagian air di daerah irigasi Kedung Bilung yang terletak di Desa Pereng, Kecamatan Mojogedang, Kabupaten Karanganyar. Kelompok tani ini dibentuk pada Minggu, 19 Juli 1993. Kelompok tani ini dibawahi oleh kelompok Tani
RukunMakaryo. Pada 22 Juni 1993 AD/ART P3A Sumber Mulyo dengan Nomer: 441.6 / 256 / 1993 telah di sahkan oleh Bupati Karanganyar sebagai P3A Sumber Mulyo di desa Pereng, Kecamatan Mojogedang Kabupaten Karanganyar.

\section{Faktor Internal Dinamika P3A Sumber Mulyo}

Pergantian pemimpin dalam sebuah kelompok tani dapat memicu timbulnya dinamika tertentu. Namun, hal tersebut belum muncul dalam P3A Sumber Mulyo karena kelompok tani ini belum pernah ada pergantian pemimpin selama kurang lebih 26 tahun. Proses penentuan ketua P3A Sumber Mulyo dilakukan dengan jalan musyawarah untuk merundingkan kandidat yang pantas menjadi ketua. Hal ini dapat menjadi salah satu hambatan secara internal kelompok tersebut. Terdapat dua hal dominan yang memberikan pengaruh terhadap pengembangan dan hambatan kemajuan internal P3A Sumber Mulyo. Dua faktor internal tersebut, yaitu (a) faktor sumber daya manusia dan (b) faktor pengetahuan dan keterampilan yang dimiliki oleh kelompok tersebut.

Tabel 1. Faktor internal yang menjadi kekuatan dan kelemahan dalam kegiatan P3A Sumber Mulyo.

\begin{tabular}{|c|c|c|c|}
\hline No. & Faktor Internal & Kekuatan & Kelemahan \\
\hline 1. & $\begin{array}{l}\text { Sumber Daya } \\
\text { Manusia }\end{array}$ & - Partisipasi Petani Tinggi & - Pendidikan petani rendah \\
\hline 2. & $\begin{array}{l}\text { Pengetahuan dan } \\
\text { Keterampilan Anggota } \\
\text { P3A }\end{array}$ & $\begin{array}{l}\text { Petani memiliki } \\
\text { Pengetahuan dan } \\
\text { Keterampilan yang baik } \\
\text { dalam bercocok tanam }\end{array}$ & $\begin{array}{l}\text { - Kurangnya Pengetahuan dan } \\
\text { Keterampilan dalam Pengelolaan } \\
\text { Air }\end{array}$ \\
\hline 3. & Kepemimpinan & $\begin{array}{l}\text { - Kepemimpinan yang } \\
\text { partisipatif }\end{array}$ & $\begin{array}{l}\text { - Lemahnya Regenerasi Pengurus } \\
\text { - Adanya rangkap jabatan dalam } \\
\text { Kepengurusan }\end{array}$ \\
\hline
\end{tabular}

Berdasarkan tabel 1, terdapat 3 kekuatan dan 4 kelemahan yang timbul dari faktor internal P3A Sumber Mulyo. Kekuatan yang dimiliki oleh P3A Sumber Mulyo, yaitu anggota kelompok tani ini dapat dikatakan tinggi dalam hal berpartisipasi dalam kegiatan yang diadakan oleh P3A Sumber Mulyo, petani memiliki pengetahuan dan keterampilan yang baik dalam bercocok tanam, serta adanya pemimpin yang turut berpartisipasi aktif dalam kegiatan yang diadakan oleh P3A Sumber Mulyo. Adapun 4 kelemahan yang timbul dari faktor internal kelompok tani ini adalah pendidikan petani rendah, kurangnya pengetahuan dan keterampilan dalam pengelolaan air, lemahnya regenerasi pengurus, serta adanya rangkap jabatan dalam kepengurusan. Hal ini juga diungkapkan oleh Santosa (2009) bahwa kepemimpinan, keanggotaan dan partisipasi masyarakat tani dapat menentukan dinamika suatu kelompok tani untuk perkembangan kelompok itu sendiri.

\section{Faktor Eksternal}

Faktor eksternal yang memicu adanya peluang dan ancaman kegiatan P3A Sumber Mulyo ini berupa perhatian dari pemerintah serta kepedulian dan kesadaran masyarakat Desa Pereng terhadap 
P3A Sumber Mulyo, dengan belum adanya petugas penyuluh lapangan dalam bidang pertanian dan pengairan. Hal ini menjadi ancaman bagi P3A
Sumber Mulyo untuk berkembang. Berikut telah disajikan dalam tabel.

Tabel 2. Faktor eksternal yang menjadi peluang dan ancaman dalam kegiatan P3A Sumber Mulyo

\begin{tabular}{llll}
\hline No. & Faktor Eksternal & Peluang & Ancaman \\
\hline 1. & Dukungan Pemerintah & $\begin{array}{l}\text { Adanya bantuan alat dari } \\
\text { Pemerintah pada awal } \\
\text { kegiatan P3A }\end{array}$ & $\begin{array}{l}\text { - Untuk saat ini, kurangnya } \\
\text { perhatian pemerintah } \\
\text { terkait kegiatan P3A }\end{array}$ \\
& & $\begin{array}{l}\text { Tingkat kepedulian dan } \\
\text { rasa memiliki masyarakat }\end{array}$ & \\
2. & $\begin{array}{l}\text { Kepedulian dan rasa } \\
\text { memiliki masyarakat sekitar } \\
\text { kelompok tani }\end{array}$ & tinggi & \\
\hline
\end{tabular}

Berdasarkan Tabel 2, perhatian dan dukungan pemerintah terhadap P3A Sumber Mulyo dapat memicu adanya peluang kelompok tani tersebut bisa berkembang. Perhatian dan dukungan tersebut telah diwujudkan pemerintah dalam wujud adanya bantuan alat dari pemerintah pada awal kegiatan P3A. Sayangnya, pemerintah masih kurang memberikan perhatian dalam bidang penyuluhan pertanian. Menurut pengakuan salah satu anggota P3A Sumber Mulyo, belum ada petugas penyuluh lapangan di Desa Pereng. Hal ini sudah terjadi cukup lama, P3A Sumber Mulyo pernah mengadukan masalah ini namun belum ada tanggapan nyata dari pemerintah. Belum adanya pengganti petugas penyuluh lapangan tersebut merupakan salah satu bukti bahwa pemerintah kurang peduli terhadap permasalahan P3A Sumber Mulyo. Jika dibiarkan, hal ini dapat memicu rasa jenuh dari petani karena pemerintah dianggap kurang perhatian dengan masalah yang terjadi. Hal ini seperti yang diungkapkan oleh Rina (2014) bahwa suatu kelompok tani memerlukan penyuluh untuk dapat menambah pengetahuan anggota dan pengurus organisasi kelompok tani. Kegiatan penyuluhan bisa membantu memberikan saran kepada anggota P3A dalam menyeleksi ketua kelompok yang memiliki sikap kosmopolit, persepsi sosial, mempunyai minat dan keyakinan dalam mencapai tujuan bersama.

Faktor kepedulian dan kesadaran masyarakat Desa Pereng juga turut andil dalam memicu peluang perkembangan kegiatan P3A Sumber Mulyo. Semangat gotong royong yang ditunjukkan masyarakat Desa Pereng merupakan motor pendorong P3A Sumber Mulyo masih tetap ada hingga saat ini. Sikap gotong royong tersebut diwujudkan dengan adanya kegiatan memperbaiki saluran irigasi dengan swadana masyarakat Desa Pereng. Hal ini dapat dikategorikan sebagai faktor eksternal karena ada sebagian petani atau masyarakat Desa Pereng yang tidak tergabung atau tidak menjadi anggota dari P3A Sumber Mulyo.

\section{Internal Factor Evaluation}

Matriks Internal Factor Evaluation (IFE) merupakan hasil pembobotan dan peratingan faktor internal yang timbul dari kegiatan P3A Sumber Mulyo. Sedangkan, Matriks External Factor Evaluation (EFE) digunakan untuk menghitung pembobotan dan peratingan faktor eksternal yang memicu adanya peluang dan ancaman kegiatan P3A Sumber Mulyo. 
Tabel 3. Matriks Internal Factor Evaluation (IFE) P3A Sumber Mulyo

\begin{tabular}{|c|c|c|c|c|c|}
\hline No. & Faktor Internal & Bobot & Rating & Bobot x Rating & Jumlah \\
\hline \multicolumn{6}{|c|}{ Kekuatan } \\
\hline 1 & Partisipasi petani tinggi & 0,182 & 4 & 0,727 & \\
\hline 2 & $\begin{array}{l}\text { Petani memiliki pengetahuan dan keterampilan } \\
\text { yang baik dalam bercocok tanam }\end{array}$ & 0,136 & 4 & 0,545 & \\
\hline \multirow[t]{2}{*}{3} & Kepemimpinan yang partisipatif & 0,182 & 4 & 0,727 & \\
\hline & \multicolumn{3}{|l|}{ Jumlah kekuatan } & & 1,999 \\
\hline \multicolumn{6}{|c|}{ Kelemahan } \\
\hline 1 & Pendidikan petani rendah. & 0,136 & 3 & 0,409 & \\
\hline 2 & $\begin{array}{l}\text { Kurangnya pengetahuan dan keterampilan } \\
\text { dalam pengelolaan air }\end{array}$ & 0,136 & 2 & 0,273 & \\
\hline 3 & Lemahnya regenerasi pengurus & 0,091 & 4 & 0,364 & \\
\hline \multirow[t]{3}{*}{4} & Adanya rangkap jabatan dalam kepengurusan & 0,136 & 3 & 0,409 & \\
\hline & \multicolumn{3}{|c|}{ Jumlah kelemahan } & & 1,455 \\
\hline & Total & 1 & & & 3,454 \\
\hline
\end{tabular}

Bedasarkan tabel 3, faktor kekuatan mencapai angka 1.999 sedangkan faktor kelemahan mencapai angka 1.455. Jika angka faktor kekuatan dan faktor kelemahan dijumlahkan, maka jumlah IFE P3A Sumber Mulyo mencapai angka 3.454. Maka dapat diidentifikasi bahwa IFE P3A Sumber Mulyo $(3,454)$ lebih besar daripada rata-rata. Hal ini menunjukkan bahwa faktor internal P3A Sumber Mulyo dapat dikatakan kuat karena mampu meningkatkan kekuatan daripada mengurangi kelemahan.

Partisipasi petani yang tinggi dengan angka bobot 0,727 menjadi faktor kekuatan terbesar dalam strategi kegiatan P3A Sumber Mulyo. Hal ini dikarenakan kesadaran petani dalam berpartisipasi dalam kegiatan yang dibuat oleh P3A Sumber Mulyo. Kegiatan-kegiatan tersebut, yaitu kegiatan gotong royong dalam penyusuran saluran irigasi setiap bulannya dan kegiatan perbaikan saluran irigasi apabila terjadi kerusakan. Hal ini disadari oleh petani guna menjaga ketersediaan air sepanjang tahun. Di sisi lain, pengetahuan dan keterampilan petani yang baik dalam bercocok tanam merupakan faktor kekuatan terkecil dengan angka bobot 0,545 . Hal ini terjadi karena petani mendapat pengetahuan dan keterampilan ketika bergabung dengan suatu kelompok tani. Padahal menurut Mardikanto (1993) upaya kelompok untuk memelihara dan mengembangkan kehidupan kelompok juga merupakan salah satu faktor pembentuk dinamika kelompok yang penting untuk diketahui.

Pendidikan petani rendah merupakan faktor kelemahan terbesar dalam strategi kegiatan P3A Sumber Mulyo. Hal ini dikarenakan pendidikan petani rendah memperoleh angka bobot 0,409 lebih tinggi daripada rangkap jabatan dalam kepengurusan, lemahnya regenerasi pengurus serta kurangnya pengetahuan dan keterampilan dalam pengelolaan air rata-rata anggota. Hasil wawancara yang dilakukan peneliti, anggota P3A Sumber Mulyo hanya mengenyam pendidikan di bangku Sekolah Dasar dan Sekolah Menengah Pertama.

Hal ini berbeda dengan penelitian yang dilakukan oleh Sugiyanto (2011). Sugiyanto menemukan bahwa rata-rata anggota P3A di Kecamatan Delanggu mengenyam pendidikan sampai dengan tamat SLTA. Selain itu, rata-rata petani yang tergabung dalam P3A tersebut berusia produktif. Sayangnya, anggota P3A tersebut memiliki tahap perencanaan yang cenderung rendah dan tahap pemanfaatan hasil yang sedang. Tetapi di sisi lain, memiliki tahap pelaksanaan yang tinggi. Dia menyatakan bahwa hubungan antara umur, pendidikan formal, luas penguasaan lahan dan pendapatan dengan tingkat partisipasi anggota P3A dalam mengelola irigasi tidak signifikan dengan uji korelasi Rank Spearman. 


\section{External Factor Evaluation}

Tabel 4. Matriks External Factor Evaluation (EFE) P3A Sumber Mulyo

\begin{tabular}{llccc}
\hline No. & Faktor Eksternal & Bobot & Rating & Bobot x Rating \\
\hline I $\quad \begin{array}{l}\text { Peluang } \\
\text { a. Adanya bantuan alat dari Pemerintah pada }\end{array}$ & 0,333 & 4 & 1,333 \\
$\quad \begin{array}{l}\text { awal kegiatan P3A } \\
\text { b. Tingkat kepedulian dan rasa memiliki } \\
\quad \text { masyarakat tinggi }\end{array}$ & 0,333 & 3 & 1,000 \\
& & & \\
II $\quad \begin{array}{l}\text { Ancaman } \\
\text { Untuk saat ini, kurangnya perhatian pemerintah } \\
\text { terkait kegiatan P3A }\end{array}$ & 0,333 & 3 & 1,000 \\
$\quad$ Jumlah & 1 & & 3.333 \\
\hline
\end{tabular}

Tabel 4 menyajikan Matriks EFE untuk menganalisis faktor-faktor eksternal yang memicu perkembangan kegiatan P3A Sumber Mulyo. Peneliti mengklasifikasi faktor-faktor eksternal tersebut menjadi peluang dan ancaman bagi perkembangan kegiatan P3A Sumber Mulyo. Peneliti juga memberikan pembobotan pada faktor-faktor eksternal yang menjadi peluang dan ancaman tersebut.

\section{Strengths Weaknesses Opportunities Threats}

Perolehan hasil dari matriks IFE dan matriks EFE dapat disusun pada matriks SWOT dengan pendekatan kuantitatif. Hal ini dapat menunjukkan posisi organisasi dalam tampilan 4 kuadran. Sumbu X dari matriks SWOT pendekatan kuantitatif diperoleh dari pengurangan skor bobot kekuatan dengan skor bobot kelemahan sehingga diperoleh angka sebesar 0,001 yang menunjukkan bahwa sumbu X bernilai positif (+). Sumbu Y dari matriks SWOT pendekatan kuantitatif diperoleh dari pengurangan skor bobot peluang dengan skor bobot ancaman sehingga diperoleh angka sebesar 0,333 yang menunjukkan bahwa sumbu $Y$ bernilai positif $(+)$. Berikut adalah gambaran matriks SWOT pendekatan kuantitatif.

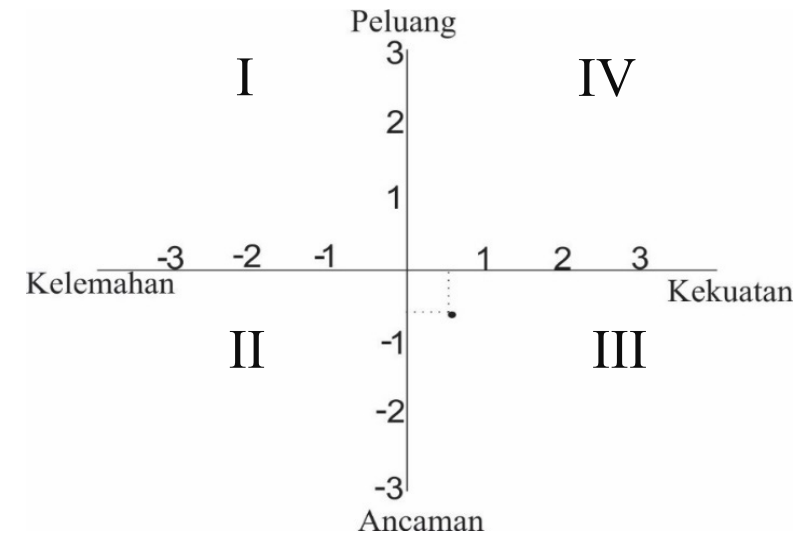

Gambar 1. Kuadran SWOT

pendekaatan kuantitatif

Berdasarakan analisis kuadran matriks SWOT dengan pendekatan kuantitatif, menunjukkan bahwa P3A Sumber Mulyo berada pada kuadran I sehingga dalam matriks SWOT pendekatan kualitatif strategi yang dirumuskan adalah strategi S-O (Stength - Oportunities). Hal ini menunjukkan bahwa matrik tersebut berada di kuadran I, yaitu positif, positif. Menurut Pearce dan Robinson (2013) sebuah organisasi yang berada di kuadran I adalah organisasi yang kuat dan mantap. Hal ini memberikan kemungkinan pada kelompok tersebut untuk meraih kemajuan yang maksimal, Perumusan strategi dengan menyesuaikan posisi organisasi ini akan menghasilkan strategi alternatif yang sesuai dengan keadaan organisasi. Perumusan strategi alternatif dengan matriks SWOT pendekatan kualitatif disajikan pada tabel berikut: 
Tabel 5. Matrik SWOT P3A Sumber Mulyo

\begin{tabular}{|c|c|c|}
\hline $\begin{array}{l}\text { Faktor } \\
\text { Eksternal }\end{array}$ & $\begin{array}{l}\text { Kekuatan (S) } \\
\text { 1. Partisipasi petani tinggi } \\
\text { 2. Petani memiliki Pengetahuan } \\
\text { dan Keterampilan yang baik } \\
\text { dalam bercocok tanam } \\
\text { 3. Kepemimpinan yang } \\
\text { Partisipatif }\end{array}$ & $\begin{array}{l}\text { Kelemahan }(\mathrm{W}) \\
\text { 1. Pendidikan petani rendah. } \\
\text { 2. Kurangnya pengetahuan } \\
\text { dan keterampilan dalam } \\
\text { pengelolaan air } \\
\text { 3. Lemahnya regenerasi pengurus } \\
\text { 4. Adanya rangkap jabatan dalam } \\
\text { kepengurusan }\end{array}$ \\
\hline $\begin{array}{l}\text { Peluang }(\mathrm{O}) \\
\text { 1. Adanya bantuan alat } \\
\text { dari Pemerintah pada } \\
\text { awal kegiatan P3A } \\
\text { 2. Tingkat kepedulian } \\
\text { dan rasa memiliki } \\
\text { masyarakat tinggi }\end{array}$ & $\begin{array}{l}\text { Strategi S-O } \\
\text { 1. Mempertahankan partisipasi } \\
\text { petani untuk membuat } \\
\text { kelompok yang mandiri. } \\
\text { 2. Mendorong anggota untuk } \\
\text { meningkatkan lagi rasa } \\
\text { kepedulian dan memiliki } \\
\text { masyarakat kepada P3A }\end{array}$ & $\begin{array}{l}\text { Strategi W-O } \\
\text { 1. Mengoptimalkan bantuan } \\
\text { alat dari pemerintah untuk } \\
\text { meningkatkan mutu pendidikan } \\
\text { petani terutama dalam bidang } \\
\text { pengetahuan dan keterampilan } \\
\text { dalam pengelolaan air. } \\
\text { 2. Menjadikan rasa kepedulian } \\
\text { yang tinggi antar masyarakan } \\
\text { untuk bersama-sama } \\
\text { meregenerasi calon pengurus } \\
\text { berikutnya supaya tidak } \\
\text { rangkap jabatan lagi untuk } \\
\text { kedepannya }\end{array}$ \\
\hline $\begin{array}{l}\text { Ancaman }(\mathrm{T}) \\
\text { 1. Untuk saat ini, } \\
\text { kurangnya perhatian } \\
\text { pemerintah terkait } \\
\text { keberlanjutan } \\
\text { kegiatan P3A }\end{array}$ & $\begin{array}{l}\text { Strategi S-T } \\
\text { 1. Menjalin komunikasi yang } \\
\text { baik dengan pemerintah } \\
\text { terkait keberlanjutan } \\
\text { kegiatan P3A }\end{array}$ & $\begin{array}{l}\text { Strategi W-T } \\
\text { 1. Tidak menjadikan kekurangan } \\
\text { petani akan pengetahuan } \\
\text { dan keterampilan dalam } \\
\text { pengelolaan air, lemahnya } \\
\text { regenerasi dan kurangnya } \\
\text { perhatian pemerintah sebagai } \\
\text { alasan untuk tidak maju dan } \\
\text { berkembang melalui pengajuan } \\
\text { proposal penyuluhan baik dari } \\
\text { pemerintah maupun civitas } \\
\text { akademika seperti PPL }\end{array}$ \\
\hline
\end{tabular}

Berdasarkan analisis pada matriks SWOT pendekatan kualitatif, diperoleh dua macam strategi alternatif yaitu mempertahankan partisipasi petani untuk membuat kelompok yang mandiri dan memberdayakan anggota untuk meningkatkan lagi kepedulian dan rasa memiliki masyarakat kepada P3A. Selain itu, sikap kerjasama dapat membantu mewujudkan tujuan program pembangunan pertanian yang berhasil dan berjalan dengan baik. Selain itu, kesediaan masyarakat atau petani dalam berpartisipasi kegiatan P3A Sumber Mulyo juga dapat mendukung keberhasilan mencapai pembangunan dan keberhasilan program kegiatan kelompok tani tanpa mengorbankan kepentingan mereka. Hal ini seperti yang dikemukakan oleh Pearce dan Robinson (2013) bahwa organisasi yang berada di kuadran I dapat diberikan rekomendasi strategi atau langkah yang progresif yang memungkinkan organisasi tersebut untuk dapat tumbuh dan berkembang secara maksimal dalam mencapai tujuan bersama.

Kepedulian masyarakat dan petani dalam kegiatan P3A Sumber Mulyo dapat tercermin pada kegiatan yang berkaitan dengan sistem irigasi. 
Beberapa petani sudah mencoba untuk mengurangi zat kimia yang dapat mengontaminasi perairan dengan menggunakan tanaman eceng gondok dan serabut kelapa. Eceng gondong ditanam dekat saluran air yang mengarah ke sawah petani. Begitu juga dengan serabut kelapa yang diletakkan di saluran air agar zat kimia yang terbawa dapat tersaring dengan baik. Sayangnya, hal ini belum dapat dibuktikan secara ilmiah. Selain itu, sawah yang berada di lingkungan P3A Sumber Mulyo dapat lebih bersih dan terhindar dari zat kimia yang terbawa oleh air dengan memperbaiki system irigasi sesuai dengan standar yang dibuat oleh Kementrian Pertanian Indonesia.

Pengembangan P3A Sumber Mulyo dapat dilakukan dengan dua langkah, yaitupengoptimalan wadah P3A untuk mengatasi berbagai masalah yang dihadapi dan pengoptimalan program penyuluhan. P3A betujuan untuk menampung masalah dan aspirasi petani yang berhubungan dengan irigasi dan bercocok tanam. P3A menjadi wadah petani untuk saling bertukar pikiran, curah pendapat serta membuat keputusan-keputusan guna memecahkan permasalahan yang dihadapi bersama. P3A juga dapat memberikan pelayanan kebutuhan petani terutama dalam hal memenuhi kebutuhan irigasi untuk usaha pertanian. Organisasi ini diharapkan dapat menjadi suatu unit usaha mandiri yang mampu menyediakan sarana produksi pertanian dan sebagainya maupun dalam upaya pemasaran. Selain itu, organisasi ini juga berperan dalam pengembangan dan pengelolaan sistem irigasi. Adanya organisasi ini diharapkan masyarakat petani dapat memiliki kemampuan untuk menilai potensi, motivasi dan keadaan dirinya sendiri, serta memiliki keterampilan merencanakan dan melaksanakan kegiatan pengelolaan irigasi secara baik, berkelanjutan dan mandiri.

Prestasi yang pernah dicapai oleh Perkumpulan Petani Pemakai Air (P3A) Sumber Mulyo sebagai juara 2 tingkat nasional tidak berarti kelompok ini memiliki nilai tambah sehingga tidak memerlukan bimbingan dari tenaga ahli. Kehadiran tenaga ahli tidak saja memberikan penyuluhan dan masukan, namun juga sebagai sarana transfer ilmu agar pengelolaan, perawatan saluran irigasi dan juga hasil panen petani dapat ditingkatkan. Sehingga, tenaga ahli yang berperan sebagai penyuluh dan pembimbing dalam hal pertanian sangat diperlukan bagi kelompok tani ini.
Penelitian ini memiliki kemiripan dengan temuan penelitian dari Zaman (2017). Hasil dari penelitian (Zaman, 2017) adalah kelompok tani Hidup Baru telah memiliki pengetahuan, pemahaman yang baik terhadap tujuan kelompok, struktur organisasi kelompok dan fungsi tugas. Selain itu, anggota kelompok tani tersebut juga dapat bekerjasama, saling mendukung dan memiliki kesempatan yang sama dalam berpartispasi mengeluarkan pendapat. Penelitian tersebut memiliki kesamaan dengan hasil dari penelitian ini karena menemukan adanya dinamika kelompok dalam perkumpulan petani di suatu daerah.

\section{KESIMPULAN}

Berdasarkan hasil penelitian, maka dapat disimpulkan bahwa faktor yang mempengaruhi dinamika kelompok P3A Sumber Mulyo, yaitu faktor internal dan faktor eksternal. Faktor internal meliputi sumber daya manusia, pengetahuan, keterampilan anggota P3A, dan kepemimpinan. Faktor eksternal meliputi adanya dukungan pemerintah dan masyarakat sekitar. Adapun hasil kegiatan dari P3A Sumber Mulyo meliputi adanya pergantian pengurus atau pendelegasian, peningkatan partisipasi anggota, ketersediaan sarana prasarana dan peningkatan hasil produksi. Pengembangkan P3A Sumber Mulyo dapat dilaksanakan dengan cara mengoptimalkan P3A sebagai wadah untuk memecahkan masalah yang dihadapi seperti pengelolaan saluran air primer, sekunder dan tersier serta pembuatan dan pengolahan pupuk organik.

\section{DAFTAR PUSTAKA}

David, F. R. (2009). Manajemen Strategis Konsep. Terjemahan oleh Dono Sunardi. Salemba Empat. Jakarta.

Departemen Pertanian. (2008). Pedoman Teknis Pengembangan Pengelolaan Irigasi Partisipatif. PT-PLA C 4.1-2008. Jakarta.

Dinar. (2015). Hubungan Pembinaan Penyuluh Pertanian Dengan Peningkatan Kemampuan Kelompok

Harsoyo, B., \& Suhadi. (1982). Irigasi dan Drainase I. Departemem Pendidikan dan Kebudayaan, Direktorat Menengah Kejuruan. Jakarta 
Hidayat, \& Suroso. (2005). Perkembangan Kinerja Perkumpulan Petani Pemakai Air di Kabupaten Banyumas Studi Kasus Daerah Irigasi Andongbang, Banjaran dan Tajum. Jurnal Pembangunan Pedesaan (Terakreditasi), Lembaga Penelitian UNSOED, Purwokerto.

Huberman, A. M., \& Matthew, B. M. (1992). Analisa Data Kualitatif; Buku Sumber Tentang Metode-Metode Baru, (Terjemahan) Tjetjep Rohendi Rohidi. Penerbit Universitas Indonesia (UI-PRESS), Jakarta.

Kuntoro. (2019). kompasiana.com. Diunduh pada 10 Mei 2019. https://www. kompasiana.com/kuntoroboga 8539 / 5 c d 52 da 595760 e 0 b 010862 b $2 /$ pertanian-membawa-ekonomi-indonesiamenjadi-5-besar-dunia

Mangkunegara, P. A. (2002). Manajemen Sumber Daya Manusia Perusahaan. Remaja Rosdakarya. Bandung

Mardikanto, T. (1993). Penyuluhan Pembangunan Pertanian. Sebelas Maret University Press. Surakarta

Novrida, M. (2008). Menyelamatkan Pangan dengan Irigasi Hemat Air. Kanisus. Yogyakarta

Pasandaran, E. (1991). Irigasi Di Indonesia. Strategi dan Pengembangan. Pengembangan dan Pemanfaatan Lahan Sawah Irigasi Oleh Wirawan dan Perkumpulan Petani Pemakai Air Di Indonesia Tradisi dan Masa Depan Oleh John S. Ambler. Unit Percetakan LP3ES. Lembaga Penelitian, Pendidikan dan Penerangan Ekonomi Sosial. Jakarta.

Pearce, J. A., \& Robinson, R. B. (2013). Management Strategies Formulasi, Implementasi dan Pengendalian. Jakarta: Salemba.
Poluan, J., Ventje, V.. Rantung, \& Charles, R. N. (2017). Dinamika Kelompok Tani Maesaan Waya Di Desa Manembo, Kecamatan Langowan Selatan. Jurnal Agri-SosioEkonomi Unsrat, Vol. 13, No. 1 A. Hal. 3.

Rangkuti, F. (2006). Analisis SWOT Teknik Membedah Kasus Bisnis: Reorientasi Konsep Prencanaan Strategis untuk Menghadapi Abad 21. Gramedia: Jakarta

Reijntjes, B. H., \& Bayer, W. (1999). Pertanian Masa Depan: Pengantar untuk Pertanian Berkelanjutan dengan Input Luar Rendah. Kanisius. Yogyakarta

Rina, Y. D., \& Panggabean, E. W. (2014). Penguatan Manajemen Mendorong Kemandirian Kelembagaan Pengelolaan Irigasi Pasang Surut di Kalimantan Selatan. Jurnal Sosek Pekerjaan Umum 6 (3): 140-221.

Rivai. (2003). Manajemen Sumber Daya Manusia. PT. Raja Grafindo Persada. Jakarta.

Santosa, S. (2009). Dinamika Kelompok. Edisi Revisi. Bumi Aksara. Jakarta

Sugiyono. (2013). Statistika untuk Penelitian. Alfabeta. Bandung.

(2017). Metode Penelitian Kuantitatif, Kualitatif, dan $R \& D$. Alfabeta Bandung.

Suryani, I. (2005). Penilaian Kinerja Keuangan untuk Memprediksi Kebangkrutan dengan Analisis Model Z-Score Altman. Skripsi. UMS. Surakarta

Syamsul, \& Dewi, Y. A. (2004). Pembaharuan Kebijakan Pengelolaan Irigasi (PKPI) dan Pemberdayaan Perkumpulan Petani Pemakai Air (P3A). Kanisus. Yogyakarta 